\title{
INDIVIDUAL VALUES AS PREDICTORS OF POSITIVE OR NEGATIVE ATTITUDES TOWARDS INNOVATION AMONG REPRESENTATIVES OF VARIOUS GENERATIONS OF RUSSIAN PEOPLE
}

\section{V.A. FEDOTOVA}

\author{
${ }^{a}$ National Research University Higher School of Economics, 38 Studencheskaya Str., Perm, 614070,
} Russian Federation

\begin{abstract}
In the last few years Russian society has been going through a stage of political, cultural and economic transformation that brings change to the lifestyle, attitudes, and the worldviews of Russian citizens. The process of development has embraced not only science and technology, but also social and cultural aspects of life. The contemporary image of Russia is in many ways defined by its younger generation that grew up with new economic, social and political standards. Young people's values, attitudes and aspirations differ from those of the adult generation of Russians, since the last years have been marked by transformations inside the country, as well as by some global changes. This paper demonstrates the results of a study which aimed to identify the relationship between individual values and attitude towards innovation. 380 respondents, young and adult representatives of the Russian population, took part in the research. The respondents belonged to the younger generation (under 25 years old) or to the adult generation (over 45 years old). The principal instrument used was the method of questionnaires. The methodical inventory consisted of three main blocks oriented to the study of the following constructs: the PVQ-R Method of Measuring individual Values (Schwartz et al., 2012) and the method of SelfAssessment of Innovative Qualities of a Personality (Lebedeva \& Tatarko, 2009). The goal of the research was to reveal the age differences in values and attitudes towards innovation, and to find which values determine positive or negative attitude towards innovations among representatives of different generations of Russians. The younger generation values of Individually Directed Thought, Stimulation, Achievement, Power/Dominance stimulate the adoption of innovations.
\end{abstract}

Keywords: cultural values, values of individual level, innovation, attitude towards innovation.

In the last few years Russian society has been going through a stage of political, cultural and economic transforma- tion that brings change into the lifestyle, attitudes, and the worldviews of Russian citizens. The process of development

This research was prepared within the framework of the Academic Fund Program at the National Research University Higher School of Economics (HSE) in 2015-2016 (Grant № 15-01-0060) and supported within the framework of a subsidy granted to the HSE by the Government of the Russian Federation for the implementation of the Global Competitiveness Program. 
has embraced not only science and technology, but also social and cultural aspects of life. Psychology of innovation is quite a new branch of psychological science, and specialists involved in the research in this field in Russia are not numerous. On a larger scale, psychology of innovation is an interdisciplinary field of knowledge that owes its development to increasing processes of globalization and modernization in the society. Today, in the world of business, innovations are not only vital for the growth of an enterprise, but also for its survival on the market. Companies have to introduce innovations in order to remain competitive in the quickly changing market conditions. Culture is one of the major factors determining a person's behaviour, including the creative behaviour; and one of the factors playing a crucial role in the way culture regulates social behaviour is whether an individual apprehends and uses the values of a given culture well enough, and then how individual values are formed. The identification of cultural values is currently one of the essential questions in psychological science in Russia and worldwide. As noted by N. Lebedeva, and later by L. Cherkasova, in spite of large amounts of research in creativity, the analysis of cultural peculiarities is frequently omitted. This is why, when planning the steps for developing innovations, one has to take into account cultural factors in the presence of which these innovations will be introduced and spread (Lebedeva, 2009; Cherkasova, 2012). Now an entire series of research papers demonstrates the existence of a connection between cultural values and the tendency of bearers of a culture to bring and accept innovations, but this con- nection has not yet been sufficiently studied. To the present moment just a few solitary instances of such research have been carried out in Russia (Lebedeva \& Gizatulina, 2009; Yasin \& Lebedeva, 2009; Lebedeva, 2008, 2009; Lebedeva \& Bushina, 2013; Lebedeva \& Grigoryan, 2014). In the West research papers on the subject of the connection of cultural values and the attitude to innovations are published more frequently (Venkataraman, McMillan, \& McGrath, 1992; Herbig \& Dunphy, 1998; Herbig \& Kramer, 1994; Jones \& Herbert, 2000), but their number is still insufficient to get the whole picture.

The contemporary image of Russia is in many ways defined by its younger generation that grew up within new economic, social and political standards. Young people's values, attitudes and aspirations differ from those of the adult generation of Russians, since the last years have been marked by transformations inside the country, as well as by some global changes. The orientation of the values shared by this active part of the society will determine the future of the country. The mere category of "value", being quite a dynamic construct, entails changes in other spheres, including the attitudes towards innovation.

\section{The problems of correlation between cultural values and innovative attitudes}

Our research is based on the idea that the general propensity to innovation can be shaped by values, and that the attitude towards innovation can be revealed at an individual level and is expressed through specific innovational attitudes. Culture is one of the major factors that determine human 
behaviour, including creative behaviour; and one of the decisive factors in a culture's regulation of social behaviour is how well the individual has assimilated the values of this specific culture, and then how individual values have formed on this background.

Smith and Bond, on the grounds of empirical research, have established the connection between the personality characteristics related to creativity and cultural values (Smith \& Bond, 1993). Creativity is bound to Openness to Change and Introversion. Masculine culture concurs with personality traits that are most advantageous for creative work. A high degree of individualism, bound to other values such as freedom of initiative, autonomy, and independence, is supposed to be important for creativity (Jones \& Herbert, 2000).

In Russian psychology the issue of innovation is the object of attention with specialists of various disciplines: sociology, economy, management, social psychology etc. Thus, Russian psychologists have conducted empirical studies of psychological readiness for innovation, which resulted in distinguishing the following social and psychological types: "active reformers", "passive reformers", "passive supporters of innovation", "self-overcoming", "inefficient", "temporizing", "blind executants", "passive opponents", and "active opponents" (Zhuravlev, 1993). The obtained results point to the reality of the multi-factor nature of innovations and the psychological readiness of various social categories of citizens for social innovation. One may suppose that representatives of different generations of Russians can also be relegated to a certain social and psychological type based on their dominant values and their attitudes towards innovation.
L. Cherkasova made an attempt to define value determinants of creative behaviour in Russia. The method of her study utilized S. Schwartz's Portrait Values Questionnaire (PVQ-R) to work out the prevailing values, and $\mathrm{S}$. Dollinger's method of assessing creative behaviour (Dollinger, Burke, \& Gump, 2007). The survey was taken by students of Moscow tertiary institutions $(\mathrm{n}=353)$. As a result of this research it was found that creative behaviour correlated to a block of values associated with Openness to Change and that there was a positive correlation between creative behaviour and attitudes to innovation with such values as Individually Directed Thought, Stimulation, Benevolence/Care and Universalism/Care for Nature. The innovativity index showed correlations to the values of Hedonism, Achievement, Power/Resources, Power/Dominance, and negatively correlated to the Conformity/Rules value orientation (Cherkasova, 2012).

Another study performed by O. Kovalyova made a distinction between two groups of people: innovators and conservators. It also contained an attempt to reveal a correlation between values and the attitude towards innovations (Lebedeva, 2009). The results of the performed multiple regression analysis showed that typical values for innovators are that of being Individually Directed (related to creativity) and Hedonism (related to the personality innovational index). For conventionalists, attitudes to innovation correlate with Stimulation and Security (which correlates with the general innovativity index of the personality and their orientation to the future). 
N.M. Lebedeva guided a research project exploring the influence of values on attitudes towards innovations in Russia and in China (Lebedeva, 2009). The research demonstrated cultural differences in the individual values of Russian and Chinese students: specifically, Russian students have a preference for values that convey the interests of individuals (Openness to Change and Self-Enhancement). The results of the multiple regression analysis of the correlation between values and attitudes towards innovation evidentiated that the value of Openness to Change favours the positive attitude to innovation, while the value of Tradition discourages it (Lebedeva, 2009).

So, culture is an important factor determining human behaviour, including creative behavior. One of the elements playing the major role in a culture's regulating social behaviour is how well the individual has assimilated values of this culture, and then, how individual values are formed. At the present moment identification of values is one of the most important problems in foreign and Russian psychology. The author's approach consists in the ideas that, firstly, a general tendency towards innovation and new developments may be conditioned by the values. Secondly, the attitude to innovation is revealed, above all, on the individual level and is expressed in specific innovational attitudes. Thirdly, the period in which an individual's values were formed has a significant impact on the attitude towards innovation, which means that the values and innovational ideas of young people are different from those of adult people.

The research conducted in the USA by $\mathrm{S}$. Dollinger and co-authors has shown that students with more apparent creativity have a different set of values compared to their less creative classmates: a strong correlation has been found between success in completing test tasks in a creative way and the preferred values of being Individually Directed, those of Stimulation, and Universalism in the older version of $\mathrm{S}$. Schwartz's theory of ten values (Dollinger, 2005, 2006).

So, a value system is an important factor determining creative behavior. The attitude towards innovation reflects, in our opinion, not only psychological preparedness for novelty, but also an individuals' willingness to generate innovation and novelty by themselves. So, the research hypotheses are:

1. There are differences within individual values: young people prefer values that express the interests of individuals and the adult generation lays weight on values pursuing the interests of a group.

2. Attitudes towards innovations differ from generation to generation: attitudes of young Russian people are more positive than those of the older generation. Creativity and Risk for Success, the General Innovativity Index of a Personality would be higher in young Russians than in their adult generation.

3. Individual values (Individually Directed Thought, Stimulation, Universalism, Hedonism, Achievement, Power/Dominance) stimulate the younger generation of Russians to accept innovation.

4. The values of Humility, Conformity/Rules, Security and Traditions have a negative correlation with positive attitude to innovation. These values form a basis for interpersonal behaviour 
in a collectivist culture and may impede the acceptance of innovations by the older generation of Russians.

\section{Method}

A principal instrument used was the method of questionnaires. The methodic inventory consists of two main blocks oriented to the study of the following constructs: the PVQ-R Method of Measuring Individual Values (Schwartz et al., 2012) and the method of Self-Assessment of Innovative Qualities of a Personality (Lebedeva \& Tatarko, 2009).

1. The PVQ-R individual values measuring method. To study the structure of values at an individual level we used a revised version of S. Schwartz's questionnaire (PVQ-R). This method contains 57 questions that allow assessing the manifestation of 19 values: Individually Directed Thought; Individually Directed Action; Stimulation; Hedonism; Achievement; Power/Dominance; Power/Resources; Reputation; Personal Security; Societal Security; Traditions; Conformity/ Rules; Interpersonal Conformity; Humility; Benevolence/Dependability; Benevolence/Care; Universalism/ Concern for Others; Universalism/ Care for Nature; and Universalism/Tolerance. The instruction is the following: "Given below are descriptions of various people. Please read each description and think how much each person is similar or not similar to you". The degree of agreement or disagreement is indicated using a 6 -point scale: 1 - not similar to me at all, 2 - not similar to me, 3 - a little similar to me, 4 - moderately similar to me, 5 - similar to me, 6 - very similar to me. At the same time every value contains three affirmations that a respondent has to assess. For instance, the Individually Directed Action value includes an assessment of the following sentences: "Broadening his mind is important to him", "Having his own point of view is important to him", "Having his own idea of things is important to him". The value of Stimulation includes such affirmations as "It is important for him to always search for variety in his activities", "He values hazard in his life even though it implies some risk", "Getting varied experience is important to him". Then, the value of Achievement comprises an assessment of these descriptions: "Having ambitious goals in life is important to him", "Being very successful is important to him", "It is important to him that people acknowledged his achievements". The Conformity/Rules value features phrases like "Never breaking a rule or an instruction is important to him", "It is important to him to respect the rules, even when no one sees him", "Complying with all laws is important to him".

2. The method of Self-Assessment of Innovative Qualities of a Personality (Lebedeva N.M., Tatarko A.N). This method represents a questionnaire that contains 15 affirmations with a 5 -points scale for assessing the agreement or disagreement: 1 - Strongly disagree, 2 - Somewhat disagree, 3 I don't know, I'm not sure, 4 - Somewhat agree, 5 - Strongly agree. Then, according to the key, points are calculated for each of the three scales that were found by means of exploratory factor analysis using the method of principal component analysis and varimax rotation of the correlation matrix (Creativity, Risk for Success, 
Orientation to the Future). The mean value of the three scales became an integral Innovativity Index of a Personality. Approbation and adaptation of this method was done during three studies (1053 respondents): the first study was conducted in 2007 with 637 respondents (360 Russians and 267 representatives of Northern Caucasus peoples); the second study was conducted in 2007-2008 with 123 managers; the third study took place in 2008 with 293 staff members of an international company.

\section{Participants}

380 respondents, young and adult representatives of the Russian population, took part in the research. The respondents belonged to the younger generation (under 25 years old) or to the adult generation (over 45 years old) (Table 1). In our study we use the following sample: college students from Moscow, Perm, St. Petersburg, Nizhny Novgorod and the adult residents of these cities. The sample embraced 203 college students from:

1. National Research University Higher School of Economics, Moscow, Russia, $\mathrm{N}=47$.

2. National Research University Higher School of Economics, Perm, Russia, $\mathrm{N}=58$.
3. National Research University Higher School of Economics, St. Petersburg, Russia, $\mathrm{N}=37$.

4. Perm State University, Perm, Russia, $\mathrm{N}=28$.

5. Perm National Research Polytechnic University, Perm, Russia, N = 33 .

Students from HSE-Perm, Perm State University and Perm National Research Polytechnic University filled out questionnaires with a researcher present; students from other universities were provided on-line questionnaires.

The sample embraced 177 adults from the above-mentioned universities (academic staff, students of second higher education) and the staff of the Ministry of Culture (Perm region).

Statistical data manipulation will be performed via a program package SPSS 21.0. Methods of mathematic and statistical manipulation will be used for the research of interrelation between cultural values and attitudes towards innovations. These methods include a comparison method with t-test, correlation analysis by the Spearman method and the method of multiple regression analysis. Also Criteria of Kolmogorov-Smirnov were also used to estimate the normalcy of distribution. To determine the internal consistency of innovational attitudes Cronbach's

Table 1

Characteristics of the respondents

\begin{tabular}{|l|c|c|}
\hline & Adult & Young \\
\hline Number & 177 & 203 \\
\hline Men (persons) & 82 & 96 \\
\hline Women (persons) & 95 & 107 \\
\hline Average age & 46 years (Max -72 Min -45$)$ & 23 years (Max -18, Min -25$)$ \\
\hline
\end{tabular}


alpha coefficient was calculated. To calculate and analyze the performance distribution center of cultural values and concepts of ethics methods of descriptive statistics will be used (median, average arithmetical, standard deviation).

\section{Results}

\section{Intergenerational differences in the individual values and attitude towards innovations}

The descriptive statistics for the PVQ-R scales are presented in Table 2.

One can see that, at the individual level, differences may be observed for the following blocks of values: Individually Directed Action, Individually Directed Thought, Stimulation, Hedonism, Achievement, Power/Dominance, Reputation, Personal Security, Traditions, Humility, Benevolence/Dependability, Benevolence/Care, Universalism/Tolerance. In this case, the values of Individually Directed Thought, Hedonism, Achievement, Power/Dominance, Personal Security, Benevolence/Dependability, Universalism/Tolerance, and Stimulation have proved to be higher in young respondents.

The significance of the intergenerational differences in the innovational attitudes is presented in Table 3 .

From the obtained data we can conclude that there are significant differences between the groups of young and adult respondents for the following innovational attitudes: Risk for Success, Orientation for the Future, and the General Innovativity Index of a Personality. These parameters are more important for young respondents who feel comfortable in an unstable environment, are ready to risk for the sake of success and to invest funds into innovation.

Each factor was analyzed from the point of view of variable coherence (see Table 4)

Cronbach's alpha evaluations on the highlighted factors have high indexes, consequently, the variables making up factors are coherent among each other and scales formed by them are valid.

\section{Interrelation between values and attitudes towards innovation}

During the study two types of analysis were used. The correlation analysis will identify the relationship between values and attitudes. And the use of the regression anlalysis provides for specific information about the nature of the dependence between the studied variables.

The results presented in Table 5 show the correlation between values and attitudes towards innovation among the adult generation of Russians.

The correlation analysis of the survey sample of adult respondents has provided evidence of significant positive correlations between Creativity and Individually Directed Action, Individually Directed Thought, Stimulation, Hedonism, Achievement, Power/Resources, Power/Dominance, Societal Security, Humility, Benevolence/Dependability Universalism/Care for Nature, Universalism/Tolerance. The values of Individually Directed Thought, Stimulation, Hedonism, Achievement, Power/Resources, Power/Dominance, Universalism/Care for Nature, and Universalism/Tolerance have positive 
Table 2

The significance of the intergenerational differences in the individual values (using t-test)

\begin{tabular}{|l|c|c|c|c|c|}
\hline \multirow{2}{*}{ Scale } & \multicolumn{2}{|c|}{ Adults } & \multicolumn{2}{c|}{ Young Russians } & Effect size \\
\cline { 2 - 7 } & M & SD & M & SD & Cohen's d \\
\hline Individually Directed Action & 5.21 & 0.63 & 4.89 & 0.59 & $0.16^{* *}$ \\
\hline Individually Directed Thought & 4.35 & 0.69 & 4.87 & 0.64 & $0.35^{* * *}$ \\
\hline Stimulation & 3.97 & 0.79 & 4.54 & 0.61 & $0.39^{* * *}$ \\
\hline Hedonism & 4.46 & 0.63 & 4.80 & 0.50 & $0.33^{* * *}$ \\
\hline Achievement & 4.46 & 0.75 & 4.98 & 0.60 & $0.29^{* * *}$ \\
\hline Power/Resources & 4.65 & .0 .89 & 4.70 & 0.89 & 0.12 \\
\hline Power/Dominance & 3.95 & 0.84 & 4.69 & 0.88 & $0.37^{* * *}$ \\
\hline Reputation & 4.93 & 0.59 & 4.72 & 0.66 & $0.16^{* *}$ \\
\hline Societal Security & 5.00 & 0.59 & 4.54 & 0.81 & 0.63 \\
\hline Personal Security & 5.83 & 0.69 & 5.28 & 0.61 & $0.15^{* * *}$ \\
\hline Conformity/Rules & 4.57 & 0.84 & 4.25 & 0.65 & $0.13^{* * *}$ \\
\hline Interpersonal Conformity & 4.84 & 0.75 & 4.29 & 0.84 & 0.69 \\
\hline Tradition & 4.26 & 0.78 & 3.98 & 0.78 & $0.19^{* * *}$ \\
\hline Humility & 5.32 & 0.60 & 4.88 & 0.48 & $0.18^{* * *}$ \\
\hline Benevolence/Dependability & 4.87 & 0.56 & 4.91 & 0.70 & $0.08^{* *}$ \\
\hline Benevolence/Care & 5.43 & 0.53 & 5.35 & 0.56 & $0.09^{* * *}$ \\
\hline Universalism/Concern for Others & 4.89 & 0.64 & 3.54 & 0.08 & 0.62 \\
\hline Universalism/Care for Nature & 3.95 & 0.71 & 4.21 & 0.92 & 0.17 \\
\hline Universalism/Tolerance & & & & & $0.15^{* * *}$ \\
\hline
\end{tabular}

Table 3

The significance of the intergenerational differences in the innovational attitudes (using t-test)

\begin{tabular}{|c|c|c|c|c|c|}
\hline \multirow{2}{*}{ Scale } & \multicolumn{2}{|c|}{ Adults } & \multicolumn{2}{|c|}{ Young Russians } & \multirow{2}{*}{$\begin{array}{l}\text { Effect size } \\
\text { Cohen's d }\end{array}$} \\
\hline & M & $\mathrm{SD}$ & M & $\mathrm{SD}$ & \\
\hline Creativity & 3.41 & 0.72 & 3.9 & 0.74 & 0.18 \\
\hline Risk for Success & 3.45 & 0.65 & 3.96 & 0.59 & $0.37^{* * *}$ \\
\hline Orientation for the Future & 3.36 & 0.63 & 3.93 & 0.62 & $0.49^{* * *}$ \\
\hline General Innovativity Index & 3.21 & 0.70 & 3.97 & 0.56 & $0.48^{* * *}$ \\
\hline
\end{tabular}

$$
{ }^{*} p<0.05,{ }^{* *} p<0.01,{ }^{* * *} p<0.001 \text {. }
$$


Variable coherence (Cronbach's alpha)

\begin{tabular}{|l|c|}
\hline \multicolumn{1}{|c|}{ Scale } & Cronbach's alpha \\
\hline Creativity & 0.8 \\
\hline Risk for Success & 0.7 \\
\hline Orientation for the Future & 0.8 \\
\hline General Innovativity Index & 0.6 \\
\hline
\end{tabular}

Table 5

Correlation of values and attitudes towards innovation: results of correlation analysis (adult generation): method of Spearman

\begin{tabular}{|l|c|c|c|c|}
\hline \multicolumn{1}{|c|}{ Values } & Creativity & $\begin{array}{c}\text { Risk for } \\
\text { success }\end{array}$ & $\begin{array}{c}\text { Orientation for } \\
\text { the future }\end{array}$ & $\begin{array}{c}\text { General inno- } \\
\text { vativity index }\end{array}$ \\
\hline Individually Directed Action & $0.17^{*}$ & $0.21^{* *}$ & 0.11 & $0.16^{*}$ \\
\hline $\begin{array}{l}\text { Individually Directed } \\
\text { Thought }\end{array}$ & $0.40^{* *}$ & $0.60^{* *}$ & $0.52^{* *}$ & $0.43^{* *}$ \\
\hline Stimulation & $0.61^{* *}$ & $0.57^{* *}$ & $0.55^{* *}$ & $0.57^{* *}$ \\
\hline Hedonism & $0.46^{* *}$ & $0.56^{* *}$ & $0.40^{* *}$ & $0.51^{* *}$ \\
\hline Achievement & $0.61^{* *}$ & $0.55^{* *}$ & $0.54^{* *}$ & $0.68^{* *}$ \\
\hline Power/Resources & $0.46^{* *}$ & $0.49^{* *}$ & $0.39^{* *}$ & $0.45^{* *}$ \\
\hline Power/Dominance & $0.62^{* *}$ & $0.65^{* *}$ & $0.54^{* *}$ & $0.60^{* *}$ \\
\hline Societal Security & $0.22^{* *}$ & $0.21^{* *}$ & -0.18 & $0.19^{* *}$ \\
\hline Personal Security & $-0.15^{*}$ & $-0.12^{*}$ & 0.56 & 0.13 \\
\hline Conformity/Rules & 0.18 & $0.29^{* *}$ & -0.37 & 0.11 \\
\hline Humility & $0.22^{* *}$ & $0.16^{*}$ & 0.29 & $0.17^{* *}$ \\
\hline Benevolence/Dependability & $0.23^{* *}$ & -0.19 & 0.55 & $0.25^{* *}$ \\
\hline Universalism/Care for Nature & $0.17^{*}$ & $0.16^{*}$ & $0.28^{* *}$ & $0.24^{* *}$ \\
\hline Universalism/Tolerance & $0.49^{* *}$ & $0.29^{* *}$ & $0.42^{* *}$ & $0.52^{* *}$ \\
\hline
\end{tabular}

$$
{ }^{*} p<0.05,{ }^{* * *} p<0.01 \text {, **** } p<0.001 \text {. }
$$

correlations with the Risk for success, Orientation for the Future, and the General Innovativity Index. Risk for Success, just like Creativity, is negatively correlated to the personal security.

We have also tested the relations between values and innovative attitu- des among adult generation using multiple regression analysis. The results are presented in Table 6.

So, the independent choice of actions and research activities, autonomy in taking decisions, the desire for power and dominance, for novelty and 
Table 6

Results of multiple regression analysis (adult generation)

\begin{tabular}{|l|c|c|c|c|}
\hline \multirow{2}{*}{\multicolumn{1}{c|}{ Independent variables }} & \multicolumn{3}{c|}{ Dependent variables } \\
\cline { 2 - 5 } & Creativity & $\begin{array}{c}\text { Risk for } \\
\text { Success }\end{array}$ & $\begin{array}{c}\text { Orientation for } \\
\text { the Future }\end{array}$ & $\begin{array}{c}\text { General } \\
\text { Innovativity } \\
\text { Index }\end{array}$ \\
\hline Individually Directed Action $\beta$ & 0.13 & $0.38^{* *}$ & 0.44 & 0.32 \\
\hline Individually Directed Thought $\beta$ & 0.86 & $0.63^{* *}$ & $0.74^{* * *}$ & $0.54^{*}$ \\
\hline Stimulation $\beta$ & $0.78^{* *}$ & 0.25 & 0.55 & $0.64^{* *}$ \\
\hline $\mathrm{R}^{2}$ & 0.56 & 0.09 & 0.19 & 0.24 \\
\hline F & $21.88^{* * *}$ & $7.26^{* *}$ & 9.63 & $19.56^{* *}$ \\
\hline Hedonism $\beta$ & 0.17 & $0.66^{* *}$ & -0.01 & $0.87^{* *}$ \\
\hline Achievement $\beta$ & $0.74^{* * *}$ & 0.28 & 0.02 & $0.64^{* *}$ \\
\hline Power/Resources $\beta$ & $0.58^{* *}$ & $0.62^{*}$ & 0.31 & $0.53^{* *}$ \\
\hline $\mathrm{R}^{2}$ & 0.23 & 0.04 & 0.18 & 0.17 \\
\hline F & $14.26^{* *}$ & $6.43^{*}$ & $7.51^{* *}$ & $11.29^{*}$ \\
\hline Societal Security $\beta$ & 0.13 & $0.3^{*}$ & 0.11 & 0.08 \\
\hline Personal Security $\beta$ & $-0.29^{*}$ & $-0.35^{*}$ & 0.27 & 0.06 \\
\hline Humility $\beta$ & $0.38^{* *}$ & $0.37^{*}$ & 0.15 & 0.13 \\
\hline $\mathrm{R}^{2}$ & 0.09 & 0.24 & 0.11 & 0.02 \\
\hline F & $13.71^{*}$ & $22.47^{* *}$ & 14.84 & 13.79 \\
\hline Benevolence/Dependability $\beta$ & $0.38^{*}$ & 0.21 & 0.11 & $0.27^{*}$ \\
\hline Universalism/Care for Nature $\beta$ & $0.24^{*}$ & 0.07 & $0.3 *$ & $0.47^{* *}$ \\
\hline Universalism/Tolerance $\beta$ & $0.56^{*}$ & $0.42^{*}$ & $0.73^{* *}$ & 0.34 \\
\hline $\mathrm{R}^{2}$ & 0.17 & 0.09 & 0.13 & 0.25 \\
\hline F & $23.54^{* * *}$ & $11.22^{* *}$ & $12.78^{* *}$ & $28^{* *}$ \\
\hline & & & & \\
\hline
\end{tabular}

${ }^{*} p<0.05,{ }^{* *} p<0.01,{ }^{* * *} p<0.001$.

deep feelings stimulate the development of creativity in adult respondents. The independence in planning actions, autonomy in taking decisions, craving for novelty, the need of achievements and the desire to control other people and resources, along with the tolerance to very different communities, are related to positive attitudes towards innovations and stimulate new inventions and developments. The need to feel protected has a negative impact on the willingness to take risks for achievements and to invest money into innovations.

At the closing stage of our work we studied correlation between values and attitudes towards innovation among the younger generation of Russians. The results are presented in Table 7 . 
The values of Individually Directed Thought, Stimulation, Achievement, Power/Resources, Power/Dominance, Conformity/Rules are in a positive correlation with Creativity, Risk for Success, Orientation for the Future and the General Innovativity Index. Besides this, the values of Societal Security, Interpersonal Conformity and Universalism/Concern for Others negatively correlate with all innovational attitudes.
Hedonism and Individually Directed Thought are positively correlated with creativity and the General Innovativity Index. So, the hypothesis can be confirmed that these values encourage positive attitude towards innovations.

After that we tested the relation between values and innovative attitudes among young generation using multiple regression analysis. The results are presented in Table 8 .

Table 7

Correlation of values and attitudes towards innovation: results of correlation analysis (young generation): Method of Spearman

\begin{tabular}{|l|c|c|c|c|}
\hline \multicolumn{1}{|c|}{ Values } & Creativity & $\begin{array}{c}\text { Risk for } \\
\text { success }\end{array}$ & $\begin{array}{c}\text { Orientation for } \\
\text { the future }\end{array}$ & $\begin{array}{c}\text { General inno- } \\
\text { vativity index }\end{array}$ \\
\hline Individually Directed Action & $0.32^{* *}$ & $0.16^{*}$ & 0.21 & $0.23^{* *}$ \\
\hline $\begin{array}{l}\text { Individually Directed } \\
\text { Thought }\end{array}$ & $0.29^{* *}$ & $0.46^{* *}$ & $0.60^{* *}$ & $0.51^{* *}$ \\
\hline Stimulation & $0.43^{* *}$ & $0.55^{* *}$ & $0.62^{* *}$ & $0.62^{* *}$ \\
\hline Hedonism & $0.20^{* *}$ & -0.77 & $0.19^{* *}$ & $0.21^{* *}$ \\
\hline Achievement & $0.35^{* *}$ & $0.35^{* *}$ & $0.23^{* *}$ & $0.36^{* *}$ \\
\hline Power/Resources & $0.48^{* *}$ & $0.44^{* *}$ & $0.43^{* *}$ & $0.53^{* *}$ \\
\hline Power/Dominance & $0.39^{* *}$ & $0.52^{* *}$ & $0.54^{* *}$ & $0.56^{* *}$ \\
\hline Reputation & $0.20^{* *}$ & $-0.18^{*}$ & $-0.21^{* *}$ & 0.14 \\
\hline Societal Security & $-0.16^{*}$ & $-0.16^{*}$ & $-0.24^{* *}$ & $-0.21^{* *}$ \\
\hline Personal Security & $0.39^{* *}$ & 0.29 & 0.33 & $0.23^{* *}$ \\
\hline Conformity/Rules & $0.16^{*}$ & $0.15^{*}$ & $0.28^{* *}$ & $0.22^{* *}$ \\
\hline Interpersonal Conformity & $-0.25^{* *}$ & $-0.43^{* *}$ & $-0.29^{* *}$ & $-0.37^{* *}$ \\
\hline Humility & $0.28^{* *}$ & 0.24 & $0.25^{* *}$ & $0.23^{* *}$ \\
\hline Benevolence/Dependability & 0.19 & $-0.27^{* *}$ & 0.11 & -0.48 \\
\hline Benevolence/Care & $0.42^{* *}$ & 0.65 & -0.32 & $0.22^{* *}$ \\
\hline $\begin{array}{l}\text { Universalism/Concern for } \\
\text { Others }\end{array}$ & $-0.32^{* *}$ & $-0.42^{* *}$ & $-0.17^{*}$ & $-0.35^{* *}$ \\
\hline Universalism/Care for Nature & 0.21 & $-0.27^{* *}$ & 0.15 & $-0.15^{*}$ \\
\hline Universalism/Tolerance & -0.54 & -0.13 & $0.25^{* *}$ & 0.29 \\
\hline & 0.001 & & \\
\hline
\end{tabular}

${ }^{*} p<0.05,{ }^{* *} p<0.01,{ }^{* * *} p<0.001$. 
Table 8

Results of multiple regression analysis (young generation)

\begin{tabular}{|c|c|c|c|c|}
\hline \multirow[b]{2}{*}{ Independent variables } & \multicolumn{4}{|c|}{ Dependent variables } \\
\hline & Creativity & $\begin{array}{l}\text { Risk for } \\
\text { Success }\end{array}$ & $\begin{array}{l}\text { Orientation } \\
\text { for the Future }\end{array}$ & $\begin{array}{l}\text { General Inno- } \\
\text { vativity Index }\end{array}$ \\
\hline Individually Directed Action $\beta$ & $0.45^{* *}$ & $0.28^{* *}$ & 0.45 & $0.37 * *$ \\
\hline Individually Directed Thought $\beta$ & 0.34 & 0.11 & $0.84^{* *}$ & $0.58 * *$ \\
\hline Stimulation & 0.09 & $0.7^{* *}$ & $0.75^{* *}$ & $0.64^{* *}$ \\
\hline $\mathrm{R}^{2}$ & 0.14 & 0.26 & 0.23 & 0.29 \\
\hline $\mathrm{F}$ & $10.09^{*}$ & $21.47 * *$ & $18.53^{* * *}$ & 25.18 \\
\hline Universalism/Care for Nature $\beta$ & 0.07 & $-0.34^{*}$ & 0.61 & 0.76 \\
\hline Hedonism $\beta$ & $0.3^{*}$ & 0.18 & 0.38 & $0.38^{*}$ \\
\hline Achievement $\beta$ & $0.47^{*}$ & $0.5^{*}$ & 0.09 & $0.46^{* *}$ \\
\hline $\mathrm{R}^{2}$ & 0.11 & 0.18 & 0.03 & 0.11 \\
\hline F & $5.74^{* *}$ & $10.23^{*}$ & 7.98 & $6.65^{*}$ \\
\hline Power/Resources $\beta$ & $0.64^{*}$ & 0.55 & $0.74^{*}$ & $0.68^{* *}$ \\
\hline Power/Dominance $\beta$ & 0.14 & $0.57^{*}$ & 0.45 & $0.68^{*}$ \\
\hline Reputation $\beta$ & 0.06 & 0.11 & 0.15 & $-0.36^{* *}$ \\
\hline $\mathrm{R}^{2}$ & 0.24 & 0.12 & 0.24 & 0.18 \\
\hline $\mathrm{F}$ & $19.36^{*}$ & $4.89^{*}$ & $19.85^{*}$ & $19.73^{* *}$ \\
\hline Societal Security $\beta$ & $-0.36^{*}$ & 0.81 & $-0.42^{*}$ & $-0.34^{*}$ \\
\hline Personal Security $\beta$ & $0.44^{* *}$ & 0.34 & 0.01 & 0.04 \\
\hline Humility & $0.24^{* *}$ & 0.13 & 0.64 & $0.48^{* *}$ \\
\hline $\mathrm{R}^{2}$ & 0.14 & 0.07 & 0.23 & 0.15 \\
\hline $\mathrm{F}$ & $8.72^{* *}$ & 8.47 & $16.79^{*}$ & $9.82^{* * *}$ \\
\hline Interpersonal Conformity $\beta$ & $-0.37^{*}$ & $-0.52^{*}$ & 0.19 & $-0.44^{*}$ \\
\hline Conformity/Rules $\beta$ & 0.13 & 0.27 & 0.63 & $0.35^{*}$ \\
\hline Benevolence/Dependability $\beta$ & $0.67^{*}$ & 0.76 & 0.22 & $0.32 * *$ \\
\hline $\mathrm{R}^{2}$ & 0.21 & 0.18 & 0.05 & 0.09 \\
\hline $\mathrm{F}$ & $13.45^{* * *}$ & $14.49^{* * *}$ & 7.92 & $10.63^{*}$ \\
\hline Universalism/Concern for Others $\beta$ & $-0.45^{* *}$ & $-0.6^{* *}$ & 0.77 & $0.49^{* *}$ \\
\hline Universalism/Care for Nature $\beta$ & 0.03 & $-0.34^{*}$ & 0.54 & 0.26 \\
\hline $\mathrm{R}^{2}$ & 0.07 & 0.15 & 0.33 & 0.16 \\
\hline $\mathrm{F}$ & $4.76^{*}$ & $9.82 * *$ & $8.49^{* *}$ & $10.70^{* *}$ \\
\hline Universalism/Concern for Others $\beta$ & $-0.45^{* *}$ & $-0.6^{* *}$ & 0.77 & $0.49 * *$ \\
\hline
\end{tabular}

${ }^{*} p<0.05,{ }^{* *} p<0.01,{ }^{* * *} p<0.001$. 
The independence in the choice of actions, autonomy, ambition, the need to be successful, craving for achievements and the desire to dominate over other people and resources stimulate the acceptance of innovations by the young generation of Russians. Other interesting results have been obtained: in particular, the values of Power/ Resource and Power/Dominance stimulate the acceptance of innovations. Interpersonal Conformity and Reputation, on the contrary, interfere with innovations.

\section{Discussion of the results}

At first we tried to find differences within individual values. From the obtained data it can be observed that the Individually Directed Action numbers are higher for adult people, and the Individually Directed Thought numbers are higher for the young Russian people. This data confirms earlier studies (Cherkasova, 2012; Lyasina, Sokolov, \& Khvan, 2014). In spite of numerous research works that testify to the independence, autonomy, activity, and self-confidence of young Russian people, many of the latter still depend on their parents and cannot always act independently only taking into account their own interests and motives. For this reason the Individually Directed Action value has higher numbers for adults, and the Individually Directed Thought value has better representation among the young generation. We also have detected differences in the values of Hedonism, Power/Dominance and Achievement, and they are more important for young people than for the adult. The principal thing in the
Hedonism group of values is delight or material pleasures, while Achievement is personal success reached through competence, in the view of existing social standards (Magun \& Rudnev, 2010). As a result, on the one hand, representatives of Russian youth long for pleasant pastimes; they find it important to enjoy life's pleasures and use any opportunity to have fun; on the other hand, they have ambitious goals in life and want to be successful. Then, numbers for the Personal Security and Conformity/Rules blocks of values are higher in young respondents, consequently, it is more important for them to feel protected, to be safe, they try to keep healthy and live an active life. Conformity is a value derived from the requirement to restrain inclinations that have a negative social impact. The importance of such values as Benevolence/Dependability and Universalism/Tolerance is also higher in the young, which proves that it is important for them to feel that their acquaintances and relatives fully believe in them and can rely on them and their help. Young people have a more expressed value of Stimulation that is understood as craving for new things and deep feelings.

Values that dominate with adult respondents are Reputation, Traditions, Humility and Benevolence/Care. For adults it is more important to maintain their reputation with other people and never to be humiliated or dishonored. For adult respondents it is more important to maintain traditional values and views, to follow family conventions or religious practices, and to honour traditions of their culture. They are modest in their behaviour and words, try not to boast, not to be arrogant, they 
do not long for public attention or approval. Schwartz divided the value Benevolence into two types: Benevolence/Care and Benevolence/ Dependability. The first type prevails with adult respondents, which means that it is important for them to take care of their loved ones, to help them, and to minister to all their needs.

Unlike representatives of the adult generation, the young people believe that changes are a way to success, current losses are not necessarily negative for the society, and opportunities are only given to those who actively search for them and show initiative. This data proves earlier studies (Cherkasova, 2012; Lyasina et al., 2014; Mastikova, 2013; Fedotova, 2015). Young respondents are more likely to accept and introduce innovation; they believe that changes are a means to gain success; they are ready to risk in order to achieve a goal; they appreciate variety in life; they are willing to create and invent new things; they are curious; they are ready to invest into innovations and feel comfortable in an unstable environment.

There is an interrelation between values and attitudes towards innovation among adults. Using correlation and regression analysis we found out that independence in the choice of actions, research activities, autonomy in taking decisions, the desire for power and dominance, for novelty and deep feelings stimulate the development of creativity in adult respondents. The independence in planning actions, autonomy in taking decisions, craving for novelty, need of achievements and desire to control other people and resources, along with the tolerance to very different communities, are related to the positive attitude towards innovations and stimulate new inventions and developments. The need to feel protected has a negative impact on the willingness to take risks for achievements and to invest money into innovations. At last, values have the impact on attitude towards innovation among adults. The values of Humility, Conformity/ Rules, Security and Traditions are fundamental for the interpersonal behaviour in collectivist cultures and may prevent the adult generation of Russians from accepting innovation. But the Societal Security value, meaning that an individual needs social order and has to be sure that the country is strong and will protect its people in case of a threat, on the contrary, stimulates the acceptance of innovations.

At the closing stage of our work we studied the correlation between values and attitudes towards innovation of the younger generation of Russians. The independence in the choice of actions, autonomy, ambition, the need to be successful, craving for achievements and the desire to dominate over other people and resources stimulate the acceptance of innovations by the young generation of Russians. Some other interesting results have been obtained: in particular, Power/Resource and Power/Dominance stimulate the acceptance of innovations. Interpersonal Conformity and Reputation, on the contrary, interfere with innovations. The desire to keep good reputation, to commit only socially approved actions, to act always in accordance with others' interests, - all of these affect negatively the processes of accepting and implementing innovations among young people. 
The research has also demonstrated the difference in the interrelation between values and innovational attitudes among different generations of Russians. The value of Societal Security in adult respondents has a positive correlation with positive attitude towards innovation, and in the young group of respondents, - a negative correlation. On the contrary, in young people Personal Security is something that obstructs innovation, and for adult respondents the impact on innovational attitudes is positive.

So, finally we can make the following conclusion:

1. The hypothesis of the variety in individual values of different generations of Russians has been partially confirmed. Young people have more expressed values of Individually Directed Action, Individually Directed Thought, Stimulation, and Universalism as in Universalism/Tolerance. For adults prevailing values are those expressing the interests of a group: Traditions, Benevolence/Care and Humility.

2. The suggested hypothesis of intergenerational differences in attitudes towards innovation finds some confirmation: young Russians' attitudes are more positive than the older generations'. Young people have a greater appreciation for such parameters as Risk for Success, Orientation to the Future, and the General Innovativity Index of a Personality.

3. The values of Humility, Conformity/Rules, Security, and Tradition constitute a foundation for interpersonal behaviour in collectivist cultures and therefore can interfere with the acceptance of innovations by the adult generation of Russians. The Personal
Security value prevents adult respondents from accepting innovations.

4. The values of Individually Directed Thought, Stimulation, Achievement, Power/Dominance, and Power/Resource stimulate young people to accept and implement innovations. Universalism/Concern for Others and Interpersonal Conformity, in their turn, impede the acceptance of innovations. Hedonism and Individually Directed Action have positive connections with Creativity and the General Innovativity Index in the Russian youth.

\section{Conclusion}

Innovation has always promised development for a society. Now that the pace of life is faster than ever before and there is an intense competition, innovational development is a necessary condition for survival, both for standalone events and an entire society. The modern innovational society should not only be open and adaptive to innovation, it should constantly generate it. Mere technical innovation is not sufficient anymore; this is why, in the contemporary world, innovational thought which is understood as the intellectual and psychological urge for novelty and new development becomes as important as innovation itself.

This research is based on the idea that a general predisposition for novelty and innovation can be conditioned by individual values. Values are not a static once-built phenomenon; they change with time, and the period in which they were formed means a lot. Individual values exert a significant influence on young people's attitude 
towards innovation, and their values and their innovational mindset are different from those of adult Russians. The data obtained as a result of our empirical study can enhance mutual understanding and adaptation skills in people of different ages working for companies and corporations. The results of our research may turn out useful in the work of administrative stuff, for instance, to develop a motivational system and to prevent conflicts, should personnel consist of both young and older staff members. Besides that, if one has an idea of various values and innovational attitudes, it will be easier for them to establish certain procedures for adaptation and training of the personnel.

\section{References}

Cherkasova, L. L. (2012). Vzaimosvyaz' kreativnogo povedeniya lichnosti, otnosheniya k innovatsiyam i tsennostei Sh. Shvartsa [The relationship of creative behavior, attitudes towards innovation and values by Sh. Schwartz]. Al'manakh Sozremennoi Nauki i Obrazozaniya, 12, 134-139.

Dollinger, S. J. (2005). A survey of creativity courses at universities in principal countries. Journal of Creative Behavior, 35, 75-88. doi:10.1002/j.2162-6057.2005.tb01251

Dollinger, S. J. (2006). Autophotographic individuality predicts creativity: a seven-year follow-up. Journal of Creative Behavior, 40, 34-48.

Dollinger, S., Burke, Ph., \& Gump, N. (2007). Creativity and values. Creativity Research Joumal, 19, 91-103.

Fedotova, V. A. (2015). Vzaimosvyaz' tsennostei i ekonomicheskikh ustanovok u predstavitelei raznykh pokolenii rossiyan [The relationship of values and economic attitudes in representatives of different generations of Russians]. Psikhologiya $v$ Ekonomike $i$ Upravlenii, 7(2), 111-120. doi:10.17150/2225-7845.2015.7(2).111-120

Herbig, P., \& Dunphy, S. (1998). Culture and innovation. Cross Cultural Management, 5, 13-21.

Herbig, P., \& Kramer, H. (1994). The effect of information overload on the innovation choice process: Innovation overload. Joumal of Consumer Marketing, 11(2), 45-54. doi:10.1108/07363769410058920

Jones, G. K, \& Herbert, J. (2000). National culture and innovation: Implications for locating Global RandD operations. Management Intemational Reviere, 40(1), 11-39.

Lebedeva, N. (2008). Cultural values, economic settings, and aptitudes towards innovations in Russia. Psychology. Joumal of Higher School of Economics, 5(2), 68-88. (in Russian)

Lebedeva, N. M. (2009). Values and attitudes to innovations: Intercultural differences. Psikhologicheskii Zhumal, 30(6), 81-92. (in Russian)

Lebedeva, N. M., \& Bushina, E. V. (2013). Vzaimosvyaz' individual'nykh tsennostei, pokazatelei sotsial'nogo kapitala i otnosheniya $\mathrm{k}$ innovatsiyam [Interrelation between individual values, social capital indicators and attitude towards innovations]. Vestnik Gosudarstvennogo Universiteta Upravleniya, 1, 288-295.

Lebedeva, N. M., \& Gizatulina, A. S. (2009). Tsennosti kul'tury i otnoshenie k innovatsiyam v mezhdunarodnoi kompanii [Cultural values and attitude towards innovation in the international company]. In N. Ivanova, V. A. Shtroo, \& N. Lebedeva (Eds.), Identichnost' $i$ organizatsiya $v$ menyayushchemsya mire: sbormik nauchrykh statei [Identity and organization in the changing world: a collection of scientific papers] (pp. 15-38). Moscow: HSE Publishing House. 
Lebedeva, N. M., \& Grigoryan, L. K. (2014). Mediativnaya rol' implitsitnykh teorii innovativnosti vo vliyanii tsennostei na otnoshenie $\mathrm{k}$ innovatsiyam [The mediative role of implicit innovation theories in the impact of values on attitudes toward innovation]. In E. G. Yasin (Ed.), XIV Aprel'skaya mezhdunarodnaya nauchnaya konferentsiya po problemam razvitiya ekonomiki i obshchestva [XVIII April International Academic Conference on Economic and Social Development] (pp. 492-502). Moscow: HSE Publishing House.

Lebedeva, N. M., \& Tatarko, A. N. (2009). Metodika issledovaniya otnosheniya lichnosti k innovatsiyam [Research method of attitudes towards innovation]. Al'manakh Sorremennoi Nauki $i$ Obrazovaniya, 4(23), 89-96.

Lyasina, I. Y., Sokolov, R. V., \& Khvan, N. S. (2014). Values differences of the Russians (application of generations theory in a regional survey). Izvestiya Volgogradskogo Gosudarstvennogo Tekhnicheskogo Universiteta, 16(143), 105-107.

Magun, V. S., \& Rudnev, M. G. (2010). Bazovye tsennosti dvukh pokolenii rossiyan i dinamika ikh sotsial'noi determinatsii [The basic values of two generations of Russians and the dynamics of their social determination]. Obshchestvennye Nauki i Sovremennost', 3, 87-97.

Mastikova, N. S. (2013). Tsennosti rossiyan: chto sleduet iz sopostavleniya statistik mezhdunarodnykh issledovanii [Values of Russians: what a comparison of the statistics of international studies manifests]. Sotsiologicheskii Zhumal, 1, 36-46.

Schwartz, S., Butenko, T. P., Sedova D. S., \& Lipatova, A. S. (2012). A refined theory of basic personal values: Validation in Russia. Psychology. Joumal of Higher School of Economics, 9(2), 43-70. (in Russian)

Smith, P. B., \& Bond, M. H. (1993). Social psychology across cultures: Analysis and perspectives. New York/London: Harvester Wheatsheaf.

Venkataraman, S., McMillan, I., \& McGrath, R. (1992). Progress in research on corporate venturing. State of the Ant in Entrepreneurship, 21(5), 931-952.

Yasin, E. G., \& Lebedeva, N. M. (2009). Culture and innovation: Approach to the problem. ForesightRussia, 3(2), 16-26. (in Russian)

Zhuravlev, A. L. (1993). Sotsial'naya psikhologiya lichnosti i malykh grupp: nekotorye itogi issledovaniya [Social Psychology of Personality and Small Groups: Results of the Study]. Psikhologicheskii Zhumal, 14(4), 4-15.

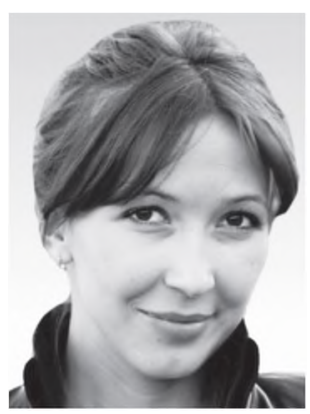

Vera A. Fedotova - senior lecturer, HSE Campus in Perm, Faculty of Economics, Management, and Business Informatics, School of Management, National Research University Higher School of Economics, master of psychology.

Research area: social psychology, business psychology, organizational psychology, general psychology, cross-cultural psychology.

E-mail: vera_goldyreva@mail.ru 


\title{
Ценности россиян в контексте межпоколенных отношений
}

\author{
В.А. Федотова ${ }^{a}$ \\ ${ }^{2}$ Национальный исследовательский университет «Высиая икола экономики», 614046, Россия, \\ Пермь, ул. Студенческая, $\partial .38$
}

\section{Резюме}

Общая предрасположенность к новаторству и нововведениям может быть обусловлена ценностями. Отношение к инновациям проявляется, прежде всего, на индивидуальном уровне и выражается в конкретных инновационных установках. Целью данного исследования выступало выявление взаимосвязи между ценностями индивида и инновативными установками и различий во взаимосвязи этих двух конструктов у представителей разных поколений россиян. В качестве респондентов выступили две группы россиян: молодое (в возрасте до 25 лет) и взрослое поколения (после 45 лет). Методический инструментарий включал методику измерения индивидуальных ценностей PVQ-R (Шварц и др., 2012) и методику «Самооценки инновативных качеств личности» (Лебедева, Татарко, 2009). В результате было выявлено, что ценности «Скромность», «Конформность-правила», «Безопасность: личная», «Традиция» мешают принятию инноваций у взрослого поколения россиян. А ценность «Безопасность: общественная», напротив, стимулирует принятие инноваций. У молодежи ценности «Самостоятельность мысли», «Стимуляция», «Достижение», «Власть: доминирование», «Власть: ресурсы» стимулируют принятие и внедрение инноваций. «Универсализм: забота о других» и «Конформизм: межличностный», наоборот, препятствуют принятию инноваций. Были также выявлены различия во взаимосвязи между ценностями и инновативными установками у представителей разных поколений россиян. А именно ценность «Безопасность: общественная» у взрослых респондентов положительно взаимосвязана с позитивным отношением к инновациям, а у молодой группы респондентов - отрицательно. Ценность «Безопасность: личная», наоборот, у молодежи препятствует принятию инноваций, а у взрослой группы респондентов положительно сказывается на инновативных установках.

Ключевые слова: культура, ценности, индивидуальные ценности, инновации, инновативные установки, взаимосвязь между ценностями и инновациями.

Федотова Вера Александровна - старший преподаватель, факультет экономики, менеджмента и бизнес-информатики, департамент менеджмента, Национальный исследовательский университет «Высшая школа экономики» (Пермь), магистр психологии.

Сфера научных интересов: социальная психология, психология бизнеса, организационная психология, общая психология, кросс-культурная психология.

Контакты: vera_goldyreva@mail.ru 